\title{
Radioactive Measurements as an Indicator of Metabolic Fluxes in Myocytes
}

\author{
Arzu Onay-Besikci*
}

Department of Pharmacology, Faculty of Pharmacy, Ankara University, Tandogan 06100, Ankara, Turkey

\begin{abstract}
Physiological, pathological and pharmacological alterations in energetic substrate metabolism have been known to contribute to effective functioning of an organ. Hence, pharmacological interventions have been shown to improve clinical symptoms of certain pathologies, such as ischemic heart disease. In order to manipulate metabolism, however, one has to be able to correctly measure and know the contribution of a particular pathway to energy production. Many methods have been developed and adapted to a wide range of techniques. Radioactive substrates have been utilized for many laboratories with success. We adapted, from well established radioactive techniques, measurements for glycolysis and glucose oxidation in $\mathrm{C} 2 \mathrm{C} 12$ myocytes. We believe that the technique is straightforward and allows the researcher to manipulate according to the needs of the laboratory.
\end{abstract}

Keywords: C2C12, glycolysis, glucose oxidation, metabolic flux.

\section{INTRODUCTION}

Manipulation of energetic substrate metabolism as a potential therapeutic intervention is a new and attractive approach to treat ischemic heart disease. Precise measurement of metabolic parameters is crucial when evaluating the rate of the pathway. This is complicated due to limitations in creating the physiological milieu with all hormones and substrates for a specific tissue.

Metabolic measurements are possible thanks to the use of radioactively-labeled substrates [1,2]. Muscle cells normally drive most of their energy from the oxidation of fatty acids and carbohydrates. Glycolysis also provides a smaller amount of energy. Two by-products of these pathways are $\mathrm{H}_{2} \mathrm{O}$ and $\mathrm{CO}_{2}$. To quantify the amount of ${ }^{3} \mathrm{H}_{2} \mathrm{O}$ or ${ }^{14} \mathrm{CO}_{2}$ as a measure of a pathway is possible if only the experimenter knows at which step of the pathway these molecules are produced.

To measure glycolysis, for example, the experimenter uses $\left[5-{ }^{3} \mathrm{H}\right]$-glucose. The radioactive label on glucose molecule is released as ${ }^{3} \mathrm{H}_{2} \mathrm{O}$ at the enolase step of glycolysis (Fig. 1). The experimenter has to collect and measure ${ }^{3} \mathrm{H}_{2} \mathrm{O}$ to determine the rate of glycolysis. The only challenge before this measurement is to separate ${ }^{3} \mathrm{H}_{2} \mathrm{O}$ from $\left[5-{ }^{3} \mathrm{H}\right]$ glucose that had not been used by the tissue/cells. This is done by a simple evaporation technique in a sealed system that is based on the vapor-phase equilibrium method [3].

When measuring glucose oxidation, the experimenter should use [U- ${ }^{14} \mathrm{C}-$ ] glucose and collect ${ }^{14} \mathrm{CO}_{2}$ that is either released into the air or trapped in the medium as carbonate. ${ }^{14} \mathrm{CO}_{2}$ is produced at the step where pyruvate is metabolized to acetyl CoA and by citric acid cycle (Fig. 2). To collect ${ }^{14} \mathrm{CO}_{2}$ is slightly difficult since it requires a sealed system not to lose any of the gas that is released into the air as well as to

*Address correspondence to this author at the Department of Pharmacology, Faculty of Pharmacy, Ankara University, Tandogan 06100, Ankara, Turkey; E-mail: onay@pharmacy.ankara.edu.tr collect the ${ }^{14} \mathrm{CO}_{2}$ that is inside the medium. Typically, a strong acid is used to release the ${ }^{14} \mathrm{CO}_{2}$ that is inside the medium and all ${ }^{14} \mathrm{CO}_{2}$ is trapped by using alkaline (such as $\mathrm{KOH}$ or benzothonium hydroxide) solutions.

These techniques have been applied successfully to metabolic flux measurements of other substrates (lactate, fatty acids) in heart perfusions and in cells and appeared in the literature countless times [1,2,4]. The techniques described here are specifically adapted and optimized for this specific cell line $(\mathrm{C} 2 \mathrm{C} 12)$ in an attempt to present at least a starting point for research in related fields.

\section{METHODS}

$\mathrm{C} 2 \mathrm{C} 12$ mouse myoblasts were grown in Dulbecco's Modified Eagle's Medium (DMEM) supplemented with 10\% fetal bovine serum (FBS), 100U/ml penicillin $G$ and $100 \mu \mathrm{g} / \mathrm{ml}$ streptomycin (growth medium). After reaching $80 \%$ confluency, the cells were differentiated in the same medium that contained 1\% FBS (differentiation medium) [5].

Cells were used in metabolic measurements only after visual confirmation of myotube formation of all myoblasts in the differentiation medium. In our system, this transformation took 10 days in the differentiation medium. In other words, all assays were performed on the $11^{\text {th }}$ day in the differentiation medium.

\subsection{Validations and Preliminary Assays}

For validation of the functionality, protein and timecourse assays were performed for each substrate (results not shown). The rate of a metabolic process should be positively correlated with the amount of cell protein and time. For example, the rate of glycolysis should increase with the increasing amount of cells and duration of incubation.

During the initial assays, we observed that the rate of a metabolic pathway was slightly different in each passage. Therefore, the effect of the treatment was compared within the same passage number. In other words, the effect of drug 


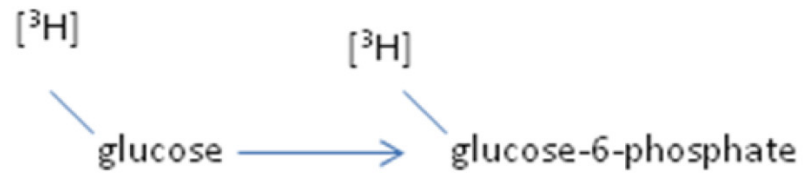

glucose $\longrightarrow$ glucose-6-phosphate

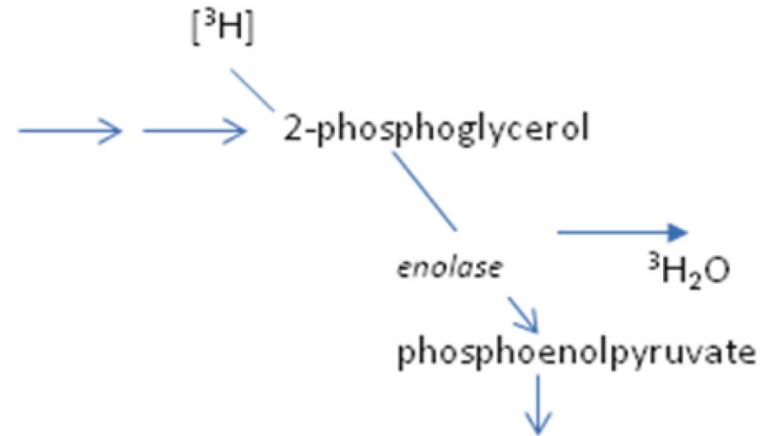

pyruvate

Fig. (1). Measurement of glycolysis by using $\left[5-{ }^{3} \mathrm{H}\right]$-glucose.

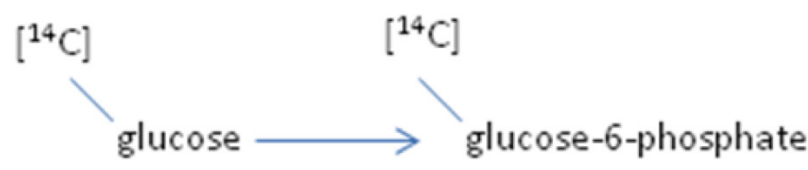

Fig. (2). Measurement of glucose oxidation by using [U- $\left.{ }^{14} \mathrm{C}-\right]$ glucose.

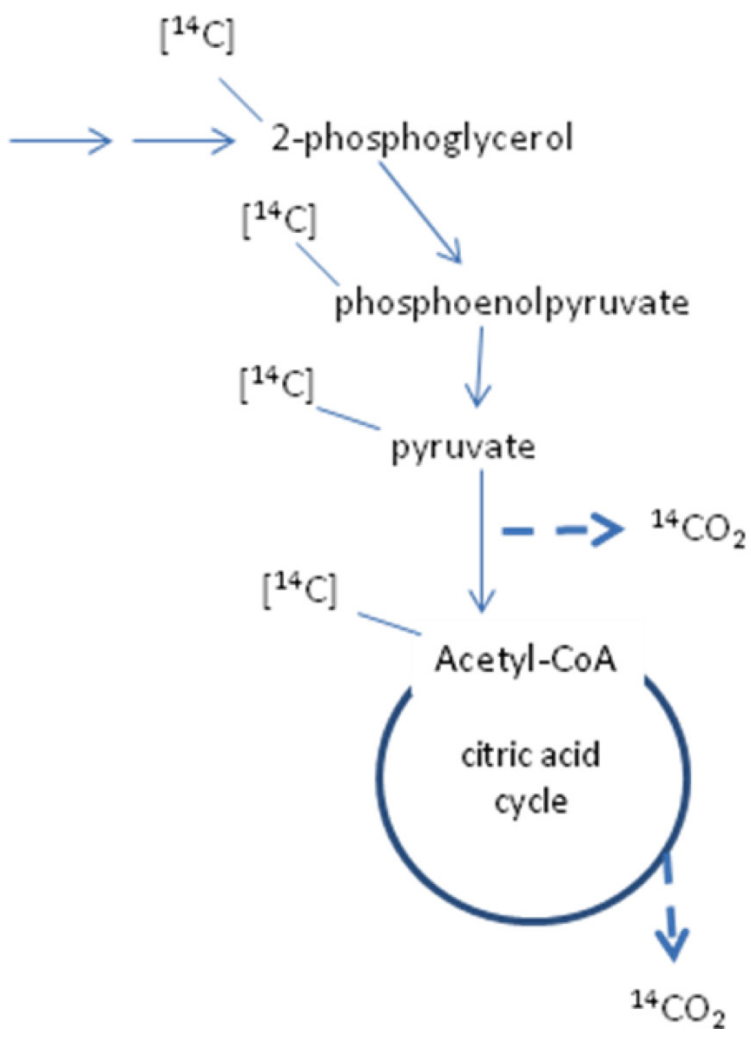

glycolysis produces ${ }^{3} \mathrm{H}_{2} \mathrm{O}$ that is released into the media. The media was collected by the end of assay. $\left[5{ }^{3} \mathrm{H}\right]$-glucose was separated from ${ }^{3} \mathrm{H}_{2} \mathrm{O}^{3}$ and the amount of ${ }^{3} \mathrm{H}_{2} \mathrm{O}$ as an indicator of glucose usage by glycolysis was measured by standard scintillation counting techniques. One $1 \mathrm{ml}$ PBS was added to each flask to scrape and transfer the cells into clean tubes where they are sonicated and prepared for protein assay [6] to determine the amount of cells in that particular flask.

\subsection{Rate of Glucose Oxidation in Resting Cells}

The cells grown and differentiated in regular $25 \mathrm{~cm}^{2}$ flasks were transferred to 6-well incubation plates for these studies. On the day before the experiment (Day 10 in differentiation medium), the cells were trypsinized as they were for regular passage procedure and divided between the 6 wells of the new plate. On the day of the experiment, the medium of the cells was replaced with fresh differention medium that contained $\left[\mathrm{U}_{-}{ }^{14} \mathrm{C}\right.$ - $]$ glucose at a specific activity 
of $250-300 \mu \mathrm{Ci} / \mathrm{mmol}$ glucose. Just before the start of the 2hours incubation, a filter paper treated with $1 \mathrm{M} \mathrm{KOH}$ was placed onto the lid of the 6-well plate. $\mathrm{KOH}$-treated filter paper trapped ${ }^{14} \mathrm{CO}_{2}$ that was produced by cells through the oxidation of $\left[\mathrm{U}_{-}{ }^{14} \mathrm{C}-\right]$ glucose. By the end of 2 hours incubation, $0.5 \mathrm{ml} \mathrm{HClO}_{4}$ was added to each well. The reason for $\mathrm{HClO}_{4}$ addition was to release the ${ }^{14} \mathrm{CO}_{2}$ that was produced by the cells and kept inside the medium. The amount of ${ }^{14} \mathrm{CO}_{2}$ that was trapped on the filter paper was determined through standard scintillation techniques as a measure of glucose oxidation [7].

\subsection{Data Processing and Statistics}

Results were shown as mean \pm sem of 5 different experiment sets as explained in previous sections. Student's t-test was used to compare 2 separate sets and statistical significance was considered to be present at $\mathrm{p}<0.05$.

\section{RESULTS AND DISCUSSION}

The metabolic rates of the cells have been evaluated in resting conditions (without the addition of any drug). Some cells were stimulated by the addition of an adrenergic receptor agonist, adrenaline. Adrenalin was used to mimic the hypercatecholamine-state which is known to stimulate the cells to metabolize higher amounts of energetic substrates compared to the resting state in order to meet the increasing demand for energy, for example, during sympathetic activation.

As shown in Fig. (3), the rate of glycolysis was $1.08 \pm$ $0.03 \mathrm{nmol}$ glucose $/ \mathrm{mg}$ in resting cells at passage number 4 . As expected, the addition of $1 \mu \mathrm{M}$ adrenaline increased the rate of glycolysis to $1.74 \pm 0.16 \mathrm{nmol}$ glucose $/ \mathrm{mg}$ (an increase of nearly 60\%). As explained in "Methods", we have been able to confirm, at following passage numbers that adrenalin stimulated glycolysis to a similar level (about $60 \%$, results not shown).

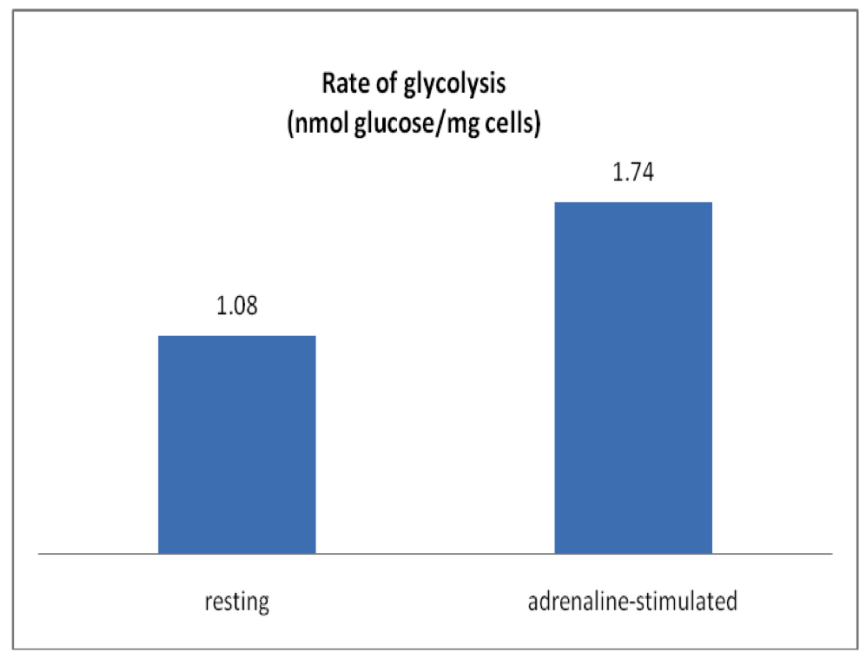

Fig. (3). Rate of glycolysis in resting (no treatment) and adrenalinetreated $\mathrm{C} 2 \mathrm{C} 12$ cells.

Next, we measured the rate of glucose oxidation in cells of passage number 6 and found that the cells metabolize $0.005 \mathrm{nmol}$ glucose $/ \mathrm{mg}$.
The substrate preference of a tissue is crucial in determining the performance and research in the field suggest that pharmacological manipulation of metabolic pathways has an exciting future in treating pathologies such as ischemic heart diseases [8-10]. A crucially important point in performing research in this area is to accurately measure the rates of the metabolic pathway in question in order to evaluate the effect of a certain manipulation. Using labeled substrates is a good tool for this and has been used for many years in different laboratory techniques such as organ perfusions and cell studies. Although not a perfect model to represent the heart tissue, the method that is presented here is optimized for $\mathrm{C} 2 \mathrm{C} 12$ cell line in our laboratory. To the best of our knowledge, a detailed methodology for the measurement of glycolysis and glucose oxidation in this cell line has not appeared in scientific literature. We therefore felt the need to report our technique and the early results to verify a functional system.

\section{CONCLUSION}

There are several limitations of this study. For example, only the metabolism of exogenous substrates that are supplied with the medium were measured. A possible contribution of endogenous stores to overall substrate usage is beyond the coverage of this technique. Moreover, we are aware of the fact that the functional work of a tissue is very important in determining the substrate preference. For example, when the workload is increased, the heart supplies its extra energy from carbohydrates. In our system, we have not been able to evaluate the contribution of function to substrate usage. However, cell studies are still very valuable for not requiring the use of animals at the early stages of a research like this presented here. Our future experiments will focus on measuring the rates of other metabolic processes and include additional pharmacological interventions.

\section{REFERENCES}

[1] Lopaschuk, G.D. Advantages and limitations of experimenta techniques used to measure cardiac energy metabolism. J. Nucl. Cardiol., 1997, 4 (4), 316-328.

[2] Barr, R.L.; Lopaschuk, G.D. Direct measurement of energy metabolism in the isolated working rat heart. J. Pharmacol. Toxicol. Methods, 1997, 38 (1), 11-17.

[3] Hughes, S.D.; Quaade, C.; Johnson, J.H.; Ferber, S.; Newgard, C.B. Transfection of Att-20(Ins) cells with Glut-2 but not Glut-1 confers glucose-stimulated insulin-secretion- relationship to glucose-metabolism. J. Biol. Chem., 1993, 268 (20), 15205-15212.

[4] Barr, R.L.; Lopaschuk, G.D. Methodology for measuring in vitrolex vivo cardiac energy metabolism. J. Pharmacol. Toxicol. Methods, 2000, 43 (2), 141-152.

[5] Perdomo, G.; Commerford, S.R.; Richard, A.M.; Adams, S.H.; Corkey, B.E.; O'Doherty, R. M.; Brown, N.F. Increased betaoxidation in muscle cells enhances insulin-stimulated glucose metabolism and protects against fatty acid-induced insulin resistance despite intramyocellular lipid accumulation. J. Biol. Chem., 2004, 279 (26), 27177-27186.

[6] Bradford, M.M. Rapid and sensitive method for quantitation of microgram quantities of protein utilizing principle of protein-dye binding. Anal.l Biochem., 1976, 72 (1-2), 248-254.

[7] Dimopoulos, N.; Watson, M.; Green, C.; Hundal, H.S. The PPAR delta agonist, GW501516, promotes fatty acid oxidation but has no direct effect on glucose utilisation or insulin sensitivity in rat L6 skeletal muscle cells. FEBS Lett., 2007, 581 (24), 4743-4748. 
[8] Revenco, D.; Morgan, J.P. Metabolic modulation and cellular therapy of cardiac dysfunction and failure. J. Cell Mol. Med., 2009, $13(5), 811-825$.

[9] Barsotti, A.; Giannoni, A.; Di Napoli, P.; Emdin, M. Energy Metabolism in the Normal and in the Diabetic Heart. Curr. Pharm. Design, 2009, 15 (8), 836-840.
[10] Lopaschuk, G.D.; Rebeyka, I.M.; Allard, M.F. Metabolic modulation - A means to mend a broken heart. Circulation, 2002, $105(2), 140-142$.

(C) Arzu Onay-Besikci; Licensee Bentham Open.

This is an open access article licensed under the terms of the Creative Commons Attribution Non-Commercial License (http://creativecommons.org/licenses/by$\mathrm{nc} / 3.0 /$ ) which permits unrestricted, non-commercial use, distribution and reproduction in any medium, provided the work is properly cited. 